\title{
Factor Identification on Consumer Behavior of Fashion Department Store in The New Normal Era of COVID-19 in Indonesia
}

\author{
Anita Rahayu $u^{1, *}$ Dona Saphiranti ${ }^{2}$,Prabu Wardono ${ }^{3}$ \\ ${ }^{1}$ Bandung Institute of Technology \\ ${ }^{2}$ Bandung Institute of Technology \\ ${ }^{3}$ Bandung Institute of Technology \\ *Corresponding author. Email: aprilianianita@gmail.com
}

\begin{abstract}
Covid-19 affects various areas of life, one of the sectors are most affected by the Covid-19 pandemic is the fashion department store industry. The implementation of social restrictions policies by the Indonesian government, followed by the increase of public awareness regarding health, have convinced consumers to undertake activities at home. Those factors brought on a change in consumer behavior of fashion department stores in Indonesia. These behavioral changes included reducing the purchase of fashion products as they are discretionary products, shifting the purchasing of fashion products through online channels, and reducing visits to public places to avoid crowds as an effort to prevent the transmission of coronavirus. During the New Normal, social restrictions were loosened that shops began to reopen, but consumers did not automatically want to visit fashion department stores. Consumers were still worried about the health risks regarding coronavirus when they revisit the store. There had been previous research about consumer behavior and retail stores during the pandemic, both in Indonesia and abroad, although there was no specific research examining consumer behavior of fashion department stores during the New Normal period in Indonesia. This study aims to identify the factors shaping the consumer behavior of fashion department stores during the New Normal in Indonesia. This study used quantitative methods with action research factor analysis. The process used online surveys to obtain data from the research population, namely fashion department store consumers in Indonesia of 258 respondents. The data were processed using statistical factor analysis to find factors shaping consumer behavior in fashion department stores during the New Normal. The results showed that eight factors shape the behavior of fashion department store consumers during the New Normal period, namely retail density, fashion department store attributes, experience, hedonic motivation, fashion product attributes, public space, motivation, and price.
\end{abstract}

Keywords: Department Store, Covid-19, Consumer Behavior, Factor Analysis.

\section{INTRODUCTION}

The Covid-19 pandemic was first discovered in Wuhan, China, at the end of 2019. The disease is caused by the severe acute respiratory syndrome coronavirus 2 (SARS-Cov-2), causing symptoms ranging from the common cold to severe symptoms such as pneumonia [1]. The virus's blistering and extensive worldwide spread caused WHO to declare coronavirus a global pandemic on March $11^{\text {th }}, 2020$. In Indonesia, Covid-19 was first detected on March $2^{\text {nd }}, 2020$, in Depok, West Java. Eleven days after the first case in Indonesia, the president formed a task force as an immediate response to Covid$19[2]$.

To prevent the spread from extending further, Indonesia implemented large-scale social restrictions or better known as PSBB. To accelerate the handling of the virus, PSBB began on March 31st, 2021, with the Ministry of Health's approval and based on the government regulation of the Republic of Indonesia number 21 of 2020. These social restrictions include school holidays, workplace holidays, religious activities, and restrictions on activities in places or general facilities. The first PSBB policy was carried out in the Jakarta area, the capital city of Indonesia, followed by several provinces and cities.[2] 
Undeniably, PSBB has a horrible impact on the Indonesian economy state. The Ministry of Finance reported that Indonesia's economic growth from January to May 2020 was $2.97 \%$, down $41.42 \%$ compared to the previous year in the same period [2]. Based upon these considerations, the Indonesian government decided to loosen the PSBB policy and lead to the New Normal [2]. The easing of PSBB did not necessarily make people want to carry out daily activities like they used to. This phenomenon happened because there has been a change in consumer behavior in Indonesia due to the Covid-19 pandemic.[3]

During the covid-19 pandemic, the fashion department store was one of the endangered sectors because it needed a physical presence to operate, and it was considered unnecessary. Hence, it became one of the business sectors that suffered the most during the pandemic considering its corporate sustainability was threatened [4]. Several months after the outbreaks and cases emerged, many fashion retails stopped operating [5]. Several challenges confronted fashion department stores during the pandemic regarding the changes in consumer behavior. First, fashion products are discretionary products that experienced a decline in purchases during the pandemic, given that the consumers preferred to buy essential products rather than fashions [3]. Second, during the Covid-19 pandemic, consumers reduced visits to public places such as department stores to avoid crowds, resulting in a shift in shopping behavior for fashion products to online platforms because it felt safer [5]. Third, when visiting physical stores, consumers would still be concerned about the health risks regarding the coronavirus.[6].

The Covid-19 pandemic will affect consumer behavior in the long term. Therefore, it is crucial to understand consumer behavior patterns properly [7]. Department stores need to redefine their role in the New Normal of Covid-19 [8] to remain relevant to the current situation. Based on this case, it is necessary to research what factors forming the behavior of department store consumers to buy fashion products during the New Normal. The theoretical basis used in this study is the theory of Kotler and Armstrong (2008) regarding consumer behavior that there are several factors influencing consumer behavior, including cultural, social, personal, and psychological factors [9].

\section{METHOD}

This study aims to identify the factors in shaping the consumer behavior of fashion department stores during the New Normal of Covid-19, which is strongly suspected to be closely related to emotional aspects, intentions, motivations, attitudes, perceptions, and social features. In such a way, the research instrument was developed based on secondary data related to the behavior of fashion consumers during the New Normal Covid-19. The department stores studied are fashion department stores for the middle-class, and the participants were the consumers located in big cities in Indonesia. The data was carried out by distributing online questionnaires via Google form from June $28^{\text {th }}$-July $4^{\text {th }}$, 2021. The total number of respondents was 258 respondents consisting of 191 women and 67 men spread across several major cities in Indonesia. Respondents were between 20-40 years old and had shopped for fashion products at department stores during the New Normal period of Covid-19. The collected data is processed and analyzed using the factor analysis statistical method using the variables found in previous studies related to fashion consumer behavior during the new normal Covid-19.

The questionnaire asked for information related to consumer demographics and respondent characteristics. The research instrument will be measured using a Likert scale, with a scale of 1 to 5 where $1=$ Strongly Disagree, $2=$ Disagree, $3=$ Uncertain, $4=$ Agree, and $5=$ Strongly Agree. There were 72 questions have been calculated, followed by the validity and reliability tests that were carried out before factor analysis. Among the questions, 21 were considered invalid, and two unreliable questions were thus, eliminated. At last, 49 valid and reliable questions were confirmed to be processed at the next stage.

\section{RESULT AND DISCUSSION}

The demographic and respondent characteristics data were processed using descriptive statistics, while responses from respondents were processed using factor analysis through the SPSS program. The results showed that most respondents by $74 \%$, were represented by women, $61.2 \%$ lived in Bandung, and $43.4 \%$ were aged between $36-40$ years old. It was found that $50 \%$ of respondents had been vaccinated, with $54.7 \%$ of respondents visited department stores that sell fashion products every three months, $70.9 \%$ of respondents spent IDR 150,000 - 750,000.00 purchasing fashion products, $35.7 \%$ shopped at fashion department stores with their 
families, and $88.8 \%$ used private vehicles to visit fashion department stores.

\subsection{Factor Analysis}

The analysis was conducted to show the relationship between several latent variables used to measure consumer behavior of fashion department stores during the New Normal of Covid-19 in Indonesia, so it forms a relevant construct. The data revealed that the value of Kaiser Mayer Olkin Measure of Sampling (KMO) met the requirements because it showed a value of 0.869 , which is above 0.5 . While the Barlett's Test of Sphericity resulted in a value of 5645,376 with a significance of 0.000 was eligible because the significance value is below $0.05(5 \%)$.

KMO and Bartlett's Test

\begin{tabular}{llr}
$\begin{array}{l}\text { Kaiser-Meyer-Olkin Measure of Sampling } \\
\text { Adequacy. }\end{array}$ & .869 \\
\hline $\begin{array}{l}\text { Bartlett's Test of } \\
\text { Sphericity }\end{array}$ & Approx. Chi-Square & 5645.376 \\
\cline { 2 - 3 } & df & 528 \\
\cline { 2 - 3 } & Sig. & .000 \\
\hline
\end{tabular}

Figure $1 \mathrm{KMO}$ and Barlett's Test

\subsection{Rotated Component Matrix}

The component matrix rotation stages (Table 1)were carried out to ensure that a variable is part of whichever factors. This process was carried out by looking at the highest correlation value between the variables and the formed factors.

\subsection{Findings}

The factor analysis process resulted in 8 factors that shape consumer behavior in fashion department stores during the New Normal period of the Covid-19 pandemic, which is explained in the description below.

The explanation of each of the factors that shape the consumer behavior of fashion department stores during the New Normal period in Indonesia is as follows in Table 2 . 
Table 1. Rotated Component Matrix

\begin{tabular}{|c|c|c|c|c|c|c|c|c|}
\hline \multirow{2}{*}{$\begin{array}{c}\text { Rotated Component } \\
\text { Matrix }\end{array}$} & \multicolumn{8}{|c|}{ Component } \\
\hline & 1 & 2 & 3 & 4 & 5 & 6 & 7 & 8 \\
\hline Perception 32 & .884 & & & & & & & \\
\hline Perception 31 & .845 & & & & & & & \\
\hline Perception 33 & .828 & & & & & & & \\
\hline Perception 34 & .806 & & & & & & & \\
\hline Perception 35 & .770 & & & & & & & \\
\hline Perception 30 & .752 & & & & & & & \\
\hline Perception 27 & .569 & & & & & & & \\
\hline Perception 10 & & .829 & & & & & & \\
\hline Perception 12 & & .822 & & & & & & \\
\hline Perception 8 & & .748 & & & & & & \\
\hline Perception 13 & & .736 & & & & & & \\
\hline Perception 7 & & .668 & & & & & & \\
\hline Perception 25 & & .411 & & & & & & \\
\hline Perception 20 & & & .851 & & & & & \\
\hline Perception 21 & & & .838 & & & & & \\
\hline Perception 22 & & & .815 & & & & & \\
\hline Motivation 12 & & & & .912 & & & & \\
\hline Motivation 11 & & & & .864 & & & & \\
\hline Motivation 13 & & & & .862 & & & & \\
\hline Perception 5 & & & & & .815 & & & \\
\hline Perception 6 & & & & & .760 & & & \\
\hline Perception 4 & & & & & .684 & & & \\
\hline Perception 1 & & & & & .648 & & & \\
\hline Motivation 19 & & & & & & .795 & & \\
\hline Motivation 17 & & & & & & .752 & & \\
\hline Motivation 18 & & & & & & .722 & & \\
\hline Perception 16 & & & & & & .513 & & \\
\hline Emotion 2 & & & & & & & .792 & \\
\hline Intention 1 & & & & & & & .766 & \\
\hline Motivation 8 & & & & & & & .533 & \\
\hline Motivation 9 & & & & & & & .487 & \\
\hline Attitude 9 & & & & & & & & .847 \\
\hline Attitude 8 & & & & & & & & .797 \\
\hline $\begin{array}{l}\text { Extraction Method: Pri } \\
\text { Rotation Method: Varir } \\
\text { a. Rotation co }\end{array}$ & $\begin{array}{l}\text { ncipal } \mathrm{C} \\
\text { nax wit } \\
\text { nverge }\end{array}$ & $\begin{array}{l}\text { ponent } \\
\text { aiser } \mathrm{Nc} \\
7 \text { iterat }\end{array}$ & $\begin{array}{l}\text { alysis. } \\
\text { alization }\end{array}$ & & & & & \\
\hline
\end{tabular}


Table 2. Findings

\begin{tabular}{|c|c|c|}
\hline \multicolumn{2}{|c|}{ Factor } & Variable \\
\hline & $\begin{array}{l}\text { Retail } \\
\text { Density }\end{array}$ & $\begin{array}{l}\text { 1. Perception 32: consumers will choose a store that is not too crowded with visitors. } \\
\text { 2. Perception 31: consumers may keep their distance from others. } \\
\text { 3. Perception 33: short queue. } \\
\text { 4. Perception 34: limit the number of consumers while in the store. } \\
\text { 5. Perception 35: stay away from crowds. } \\
\text { 6. Perception 30: keep their distance from the others. } \\
\text { 7. Perception 27: prefer stores with lesser collections. }\end{array}$ \\
\hline 2. & $\begin{array}{l}\text { Department } \\
\text { store's } \\
\text { Attributes }\end{array}$ & $\begin{array}{l}\text { 1. Perception 10: clear area information board. } \\
\text { 2. Perception 12: clear product information board. } \\
\text { 3. Perception 8: provide complete shopping equipment. } \\
\text { 4. Perception 13: a green area for the atmosphere in the store will be more } \\
\text { tranquil. } \\
\text { 5. Perception 7: provide complete shopping facilities. } \\
\text { 6. Perception 25: provide a hygiene-guaranteed fitting room. }\end{array}$ \\
\hline 3. & Experience & $\begin{array}{l}\text { 1. Perception 20: able to see fashion products. } \\
\text { 2. Perception 21: able to try fashion products. } \\
\text { 3. Perception 22: able to choose the right size of fashion products }\end{array}$ \\
\hline 4. & Hedonic & $\begin{array}{l}\text { 1. Motivation 12: buy fashion products for inner satisfaction. } \\
\text { 2. Motivation 11: buy fashion products for pleasure. } \\
\text { 3. Motivation13: buy fashion products to makes feel better. }\end{array}$ \\
\hline 5. & $\begin{array}{l}\text { Physical } \\
\text { Product }\end{array}$ & $\begin{array}{l}\text { 1. Perception 5: comfortable-to-wear products } \\
\text { 2. Perception 6: well-functioned fashion products } \\
\text { 3. Perception 4: styled following consumers' preferences } \\
\text { 4. Perception 1: good qualities fashion products. }\end{array}$ \\
\hline 6. & $\begin{array}{l}\text { Public } \\
\text { Space }\end{array}$ & $\begin{array}{l}\text { 1. Motivation 19: having quality time with friends and family } \\
\text { 2. Motivation } 17 \text { : eating out } \\
\text { 3. Motivation 18: working space } \\
\text { 4. Perception 16: eating areas }\end{array}$ \\
\hline 7. & Motivation & $\begin{array}{l}\text { 1. Emotion 2: eager to visit stores in the New Normal period } \\
\text { 2. Intention 1: wanted to visit stores if the PSBB policy is loosened } \\
\text { 3. Motivation 8: prefer purchasing fashion products at department stores because } \\
\text { it is easier. } \\
\text { 4. Motivation 9: feel more comfortable shopping at department stores }\end{array}$ \\
\hline & Price & $\begin{array}{l}\text { 1. Attitude 9: consider the price calculations when buying fashion products. } \\
\text { 2. Attitude 8: buy fashion products on sale. }\end{array}$ \\
\hline
\end{tabular}




\section{Factor 1: Retail Density Factor}

- Consumers will choose stores that are not too full of visitors, this is following the research conducted by Potia and Praceso (2020) that consumers prefer stores that are not too full of visitors when trying to shop at a new shopping place during the pandemic.

- Consumers will reduce direct contact with other people, this is following with a survey conducted by Potia and Praceso (2020) that one of the considerations of consumers when deciding to shop at a store is to reduce direct contact when making a purchase. This is also following by research conducted by Brandtner et al (2021) that consumers prefer stores that have a supportive layout to reduce direct contact with other people.

- Consumers will choose stores with short queues, this is in following research [10] [11] that to reduce direct contact with other people consumers will not linger in the store. So they will choose a shop with a short queue [3] [11].

- Limiting the number of consumers is one of the considerations for consumers when shopping at fashion department stores, this is following with previous research that one of the easiest ways to reduce congestion in the store is to reduce the number of consumers who are in the store at one time [10] [4].

- During the new normal, consumers will stay away from the crowd when they are in the fashion department store area. This is following previous research that consumers want to maintain a safe distance and avoid "crowding stress" so that one way consumers feel safe in pr12/11/21 3:28:00 PMeventing the transmission of Covid-19 effectively is to stay away from crowds [4]

- Consumers will shop in stores by keeping their distance from other people. This is following previous research that one of the priorities of consumers when deciding to shop at department stores is safe social distancing [3].

- The density factor of displaying products sold also affects consumer behavior in choosing fashion department stores during the new normal, this is following by research that consumers will choose stores that are not too crowded in displaying their products[12].

Some of these forming variables are following previous research that retail density is one of the factors shaping consumer behavior in department store fashion during the new normal period of Covid-19, this is because consumers want to reduce the risk of contracting COVID-19 while they visit the store.

Factor 2: Department Store Attributes Factor
- The existence of a clear area information board in a fashion department store is following Brandtner et al (2021) research that during a pandemic, consumers prefer to visit stores that have a clear layout and marking information. This is because the signage of the shop area will make it easier for consumers to find the products they need quickly and make it easier for consumers to move around in the store[13]. Moreover, according to research conducted by Trotter (2020), information boards can make it easier for consumers to find out any changes to the layout in the store that may have to be made related to the Covid-19 pandemic.

- The store must provide clear product information media. This is in following research conducted by Chan et al. (2020), that the direction to buy the right product is one of the considerations for consumers when shopping for fashion products during the new normal.

- Stores must provide shopping equipment. This is following the findings of Dabholkar et al. (1995) that shopping equipment such as shopping bags and catalogs can make it easier for consumers to shop for fashion products.

- During the new normal, consumers will prefer fashion department stores that provide green areas. This is following the statement of Peters et al (2020) that consumers need green areas, trees, and parks for a more relaxed atmosphere.

- Stores must provide complete facilities. This is following research conducted by Brandter et al (2021) that the physical aspects of stores such as store layouts and facilities are important factors that shape consumer sentiment during the Covid19 pandemic.

- Consumers will choose fashion department stores that provide safe fitting rooms. During the new normal period of the Covid-19 pandemic, there is a fear of the risk of being infected when in a closed room. This is following explanation that it is very important for consumers when shopping for fashion products at department stores to be able to try products in safe fitting rooms [15].

Based on this explanation, the department store attribute factors found in this study are following the findings of previous studies that department store attributes are one of the consumer considerations in visiting fashion department stores.

\section{Factor 3: Experience Factor}

- Consumers need to be able to see the product directly. This is following the results of research conducted by Chan et al (2020) that when shopping for fashion products at department stores, consumers want to have the option of being able to see products directly. 
- The advantage of shopping for fashion products at department stores compared to shopping online is that consumers can try the products directly. This is following the research of Chan et al (2020) that one of the considerations of consumers in choosing a store to buy fashion products is that consumers can try products directly at department stores.

- Consumers want to be able to choose the right product size directly when buying fashion products. This is following the research results of Chan et al (2020) that the main obstacle felt by consumers when shopping for fashion products online is the difficulty of choosing the right clothing size. However, if consumers buy the product directly at the fashion department store, consumers can choose the right fashion product directly.

During the Covid-19 pandemic, there has been a shift in the way of shopping. To reduce physical contact with other people to prevent the spread of Covid-19, consumers prefer to buy products online. However, the advantage of physical stores such as fashion department stores compared to online stores is that consumers can see, touch, and choose the right products directly. This is following previous studies related to the shopping experience.

\section{Factor 4: Hedonic Factor}

- Consumers visit fashion department stores during the new normal for fun. Shopping for fashion products at fashion department stores during a pandemic can be a fun activity. This is following the research conducted by Knowles et al (2020).

- Shopping for fashion products is an entertaining thing. According to previous research, shopping for fashion products at fashion department stores during a pandemic can be an entertaining activity. This is because, during the Large-Scale Social Restrictions (PSBB), consumers are limited to doing recreational activities [7].

- Shopping for fashion products at department stores during the new normal can make a better feeling. This is following previous research that one of the goals of consumers to shop for fashion products at department stores is because this activity can make a better feeling [16].

The government's policy to prevent the spread of Covid19 which is large-scale social restrictions (PSBB) has made consumers do a lot of activities at home. Following previous research, this causes some consumers to feel bored at home and want to go to the store to escape from the routine during the pandemic by visiting fashion department stores if the health risks related to Covid-19 are relatively low.

\section{Factor 5: Fashion Product Attributes Factor}

- The factor of choosing fashion products that are comfortable to wear is following previous research that during the Covid-19 pandemic, consumers spend more time at home [3]. Therefore, during the new normal, consumers are more considerate of buying comfortable fashion products to support their activities at home [17].

- Consumers will choose fashion products that function well. This is following previous research that one of the attributes of fashion products that are considered by consumers in the new normal is that fashion products can function properly [17].

- The consumer will choose fashion products according to the preferred style. This is following previous research by Granskog et al (2020) that consumers prefer to buy products according to their preferred style. Moreover, according to research by Granskog et al (2020), the attribute of fashion products in the form of the latest trends is an unimportant factor when purchasing fashion products. This shows that there has been a shift in the fashion cycle mindset in fashion consumers.

- The consumer will choose fashion products with good quality. This is following previous research that during the new normal period of Covid-19, consumers choose to buy fashion products with good quality due to increased awareness of the sustainability of fashion products. So that by buying fashion products with good quality, it is hoped that the products can last long after the Covid-19 crisis has passed [14].

The fashion product attributes factor is one of the considerations for consumers in buying fashion products at department stores during the new normal Covid-19. This is following previous research that during the pandemic, consumer awareness of sustainable fashion products is increasing.

\section{Factor 6: Public Space Factor}

- The factor of being able to chat with friends and family is following previous research that when social restrictions are relaxed, consumers will need more social interaction [18]. Therefore, when visiting department stores, consumers hope to be able to simultaneously conduct social activities such as chatting with friends and family.

- The factor of being able to dine out is following with previous research that there is a need for consumers to be able to simultaneously dine out while shopping [18]. Moreover, dining out is an activity that cannot be replaced online.

- The "working space" factor is following previous research that department stores must be 
able to become one of the new destinations that offer other facilities such as facilities for work [18]. During the new normal Covid-19, following the previous research, there is a consumer need for public areas that can support their activities during this new normal.

- There is the need to eating out when visiting department stores, fashion department stores need to provide dining area facilities, this is following previous research that consumers need a dining area when visiting stores[18]

In the new normal era, the fashion department store needs to redefine its role, not only as a place to shop but also as a place where people can socialize considering that during a pandemic social activity are very limited. During the new normal, people may need more social activities.

\section{Factor 7: Motivation Factor}

- When shopping for fashion products, consumers are eager to visit department stores. Following a previous study by Knowles (2020), consumers are feeling excited about the reopening of shops as social restrictions have been relaxed.

- Consumers want to visit department stores if the PSBB is relaxed. This is following previous research that consumers plan to visit physical stores such as department stores once the PSBB is relaxed (Chan, 2020).

- Buying fashion products is easier at department stores. This is following previous research by Koch et al (2020) that one of the reasons consumers shop for fashion products at department stores is because of the sense of convenience to shopping.

- In the new normal period of Covid-19, buying fashion products still feels more comfortable at department stores. This is following previous research by Koch et al (2020) that for consumers, shopping for fashion products at department stores feels comfortable.

The factors that motivate consumers to revisit fashion department stores in this study are in line with previous studies. This is one of the factors that shape consumer behavior in coming back to fashion department stores during the new normal Covid-19.

\section{Factor 8: Price Factor}

- In the new normal, consumers consider price more when buying fashion products. This is following with previous research by Potia and Preseco (2020) that during the new normal period of Covid-19 in Indonesia, consumers will consider price more before buying fashion products.

- Consumers will prefer to buy fashion products if there is a discount. This is following previous research by Chan et al (2020) that during the new normal period of Covid-19, consumers prefer to buy products that provide discounted prices.

Economic uncertainty due to the Covid-19 pandemic, according to previous research, has made consumers more cautious when shopping for fashion products. This affects the purchase of fashion products during the new normal period of Covid-19.

\section{CONCLUSION}

This study aims to find the factors shaping the consumer behavior of fashion department stores during the New Normal Covid-19 using the factor analysis

method. There were several new indicators regarding the consumer behavior of fashion department stores while this research was conducted. Some of these factors were emotions related to Covid-19, preventive measures for Covid-19 infection possibility in fashion department stores, the feeling of safety while in fashion department stores regarding coronavirus, also crowds and social distancing while in stores. The researchers found eight factors in shaping consumer behavior of department store fashion, namely retail density factor, department store attribute, experience, hedonic, product physical, public space, motivation, and price factor. Of all the eight aspects, the retail density factor is the most related to the Covid-19. During the pandemic, consumers become more aware of the need for space to practice social distancing. Since it was to prevent contracting the coronavirus while in a fashion department store. It is expected that these findings could perhaps contribute to an understanding of the consumer behavior preferences of fashion department stores during the New Normal period of the Covid-19 pandemic and may be used as a reference for designers and fashion department store businesses.

\section{REFERENCES}

[1] WHO. Coronavirus [Internet]. 2020 [cited 2021 Jun 30]. Available from: https://www.who.int/westernpacific/healthtopics/coronavirus

[2] Irawan MZ, Rizki M, Joewono TB, Belgiawan PF. Exploring the intention of out-of-home activities participation during new normal conditions in Indonesian cities. Transportation Research Interdisciplinary Perspectives. 2020 Nov;8:100237.

[3] Potia A, Praseco D. Indonesian consumer sentiment during the coronavorus crisis. $2020 \mathrm{Nov}$ 6; Available from: https://www.mckinsey.com/business- 
functions/marketing-and-sales/our-insights/surveyindonesian-consumer-sentiment-during-thecoronavirus-crisis

[4] Ntounis N, Mumford C, Loroño-Leturiondo M, Parker C, Still K. How safe is it to shop? Estimating the amount of space needed to safely social distance in various retail environments. Safety Science. 2020;132:104985.

[5] Youn S, Lee JE, Ha-Brookshire J. Fashion Consumers' Channel Switching Behavior During the COVID-19: Protection Motivation Theory in the Extended Planned Behavior Framework. Clothing and Textiles Research Journal. 2021 Apr;39(2):139-56.

[6] Knowles J, Lynch P, Baris R, Ettenson R. As Stores Reopen, Which Customers Are Most Likely to Return? 2020;21.

[7] Koch J, Frommeyer B, Schewe G. Online Shopping Motives during the COVID-19 Pandemic - Lessons from the Crisis. Sustainability. 2020 Dec 8;12(24):10247.

[8] Adhi P, Davis A, Jayakumar J, Touse S. Reimagining stores for retail's next normal. 2020;6.

[9] Kotler P, Amstrong G. Prinsip-prinsip Pemasaran. Vol. 1. Erlangga; 2008.

[10] Shumsky R, Debo L. What safe shopping looks like during the pandemic. 2020; Available from: https://hbr.org/2020/07/what-safe-shopping-lookslike-during-the-pandemic

[11] Brandtner P, Darbanian F, Falatouri T, Udokwu C. Impact of COVID-19 on the Customer End of Retail Supply Chains: A Big Data Analysis of Consumer Satisfaction. Sustainability. 2021 Jan 30;13(3): 1464.

[12] Trotter C. How will retail store designs change post-Covid? 2020 May 28; Available from: https://www.insider-trends.com/how-will-retailstore-designs-change-post-covid/

[13] Dabholkar PA, Thorpe DI, Rentz JO. A Measure of Service Quality for Retail Stores: Scale Development and Validation. Journal of the Academy of Marketing Science. 1995;3-16.

[14] Chan S, Chugh M, Poh F, Wintels S.

Discreationary spending in Indonesia amid and after the Covid-19 pandemic [Internet]. 2020. Available from: https://www.mckinsey.com/industries/retail/our- insights/survey-discretionary-spending-inindonesia-amid-and-after-the-covid-19-pandemic

[15] Stewart J. Are Dressing Rooms Safe? How To Try On Clothes Now That Stores Are Reopening During COVID [Internet]. 2020 [cited $2021 \mathrm{Jul}$ 14]. Available from: https://www.thezoereport.com/p/are-dressingrooms-safe-how-to-try-on-clothes-now-that-storesare-reopening-during-covid

[16] Widyasari R. Factors That Determined E-Purchase Decision in Fashion Industry for Gen $\mathrm{Y}$ and $\mathrm{Z}$. PSYCHOLOGY AND EDUCATION. 2020;11.

[17] Granskog A, Lee L, Magnus K-H, Sawers C. Survey: Consumer sentiment on sustainability in fashion. 2020;9.

[18] Peters T, Penalosa M, Nolan K, MacLeod J. The future of the mall - Building a new kind of destination for the post-pandemic world. 2020;20. 